\title{
PENGARUH VARIABEL MAKROEKONOMI TERHADAP INDEKS HARGA SAHAM SYARIAH (STUDI KASUS DI INDONESIA DAN MALAYSIA)
}

\author{
Desy Trishardiyanti Adiningtyas \\ Institut Agama Islam Negeri Salatiga \\ E-mail: trishardiyantidesy@gmail.com
}

\begin{abstract}
The Effect of Macroeconomic Variables on Sharia Stock Price Index (Case Study in Indonesia and Malaysia). The purpose of this research is to know the effect of macroeconomic variables (inflation, exchange rate, world crude oil price and world gold price) on sharia stock price index in Indonesia and Malaysia. By using Error Correction Model as the method, this research utilizes time series monthly data from March 2015 until February 2018. The finding shows that in long-term, inflation in Indonesia, exchange rate of rupiah, world crude oil price and world gold price had significant effect on Jakarta Islamic Index. In short-term, inflation in Indonesia, world crude oil price, world gold price had not significant effect on Jakarta Islamic Index and exchange rate of rupiah had significant effect on Jakarta Islamic Index. Meanwhile, inflation in Malaysia, world crude oil price, world gold price had not significant effect on FTSE Bursa Malaysia Hijrah Syariah Index in long-term and short-term. And exchange rate of ringgit had significant effect on FTSE Bursa Malaysia Hijrah Syariah Index in long-term and short-term.
\end{abstract}

Keywords: Macroeconomic variables, Sharia stock price index.

Abstrak. Pengaruh Variabel Makroekonomi Terhadap Indeks Harga Saham Syariah (Studi Kasus di Indonesia dan Malaysia). Tujuan dari penelitian ini adalah untuk mengetahui pengaruh variabel makroekonomi (inflasi, kurs, harga minyak mentah dunia dan harga emas dunia) terhadap indeks harga saham syariah di Indonesia dan Malaysia. Penelitian ini menggunakan metode Error Correction Model, dengan data time series bulanan dari Maret 2015 sampai dengan Februari 2018. Hasil penelitian ini menunjukan bahwa pada jangka panjang, inflasi Indonesia, kurs rupiah, harga minyak mentah dunia dan harga emas dunia berpengaruh terhadap Jakarta Islamic Index. Pada jangka pendek, inflasi Indonesia, harga minyak mentah dunia, harga emas dunia tidak berpengaruh terhadap Jakarta Islamic Index dan kurs rupiah berpengaruh terhadap Jakarta Islamic Index. Sementara itu, inflasi Malaysia, harga minyak mentah dunia, harga emas dunia tidak berpengaruh terhadap FTSE Bursa Malaysia Hijrah Syariah Index pada jangka panjang dan jangka pendek. Dan kurs ringgit berpengaruh terhadap FTSE Bursa Malaysia Hijrah Syariah Index pada jangka panjang dan jangka pendek.

Kata kunci: Variabel makroekonomi, Indeks harga saham syariah. 


\section{PENDAHULUAN}

Di dalam pasar modal Indonesia terdapat indeks yang bernama Jakarta Islamic Index yang diluncurkan berdasarkan prinsip syariah pada tanggal 3 Juli 2000. Tujuan Jakarta Islamic Index yang melibatkan 30 saham terpilih adalah sebagai tolak ukur (benchmark) untuk mengukur kinerja investasi pada saham yang berbasis syariah dan meningkatkan kepercayaan para investor untuk mengembangkan investasi dalam ekuiti syariah ${ }^{1}$. Berikut ini adalah pergerakan Jakarta Islamic Index selama periode Maret 2015 sampai dengan Februari 2018:

Gambar 1

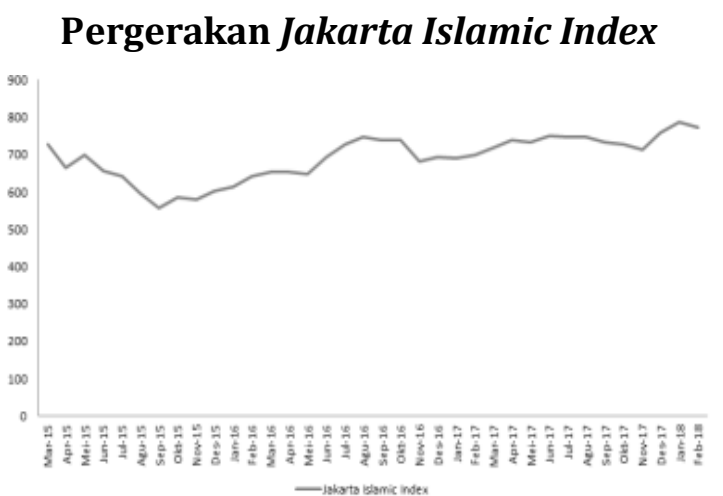

Di pasar modal Malaysia terdapat indeks yang bernama FTSE Bursa Malaysia Hijrah Syariah Index, indeks ini dirancang untuk digunakan sebagai dasar produk investasi syariah yang memenuhi persyaratan screening dari investor syariah internasional. Efek yang masuk dalam indeks tersebut disaring oleh Shariah Advisory Council Malaysia dan konsultan syariah global terkemuka,Yasaar Ltd ${ }^{2}$. Berikut ini adalah pergerakan FTSE Bursa Malaysia Hijrah Syariah Index selama periode Maret 2015 sampai dengan Februari 2018:

\section{Gambar 2}

\section{Pergerakan FTSE Bursa Malaysia Hijrah Syariah Index}

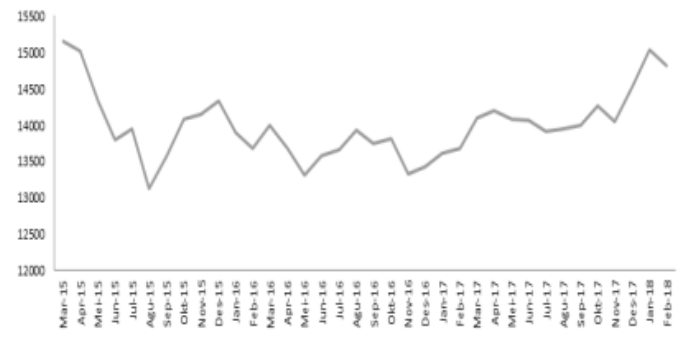


Desy Trishardiyanti A.: Pengaruh Variable...

Pada gambar 1 dan gambar 2 di atas, pergerakan Jakarta Islamic Index dan FTSE Bursa Malaysia Hijrah Syariah Index selama periode Maret 2015 sampai dengan Februari 2018 mengalami fluktuasi, fluktuasi pergerakan Jakarta Islamic Index dan FTSE Bursa Malaysia Hijrah Syariah Index tersebut tentunya dipengaruhi oleh berbagai faktor, antara lain kurs, harga minyak mentah dunia, harga emas dunia dan inflasi.

Hubungan antara kurs dengan indeks harga saham dapat dilihat melalui pendekatan pasar barang. Pada saat kurs mata uang domestik terhadap mata uang asing terdepresiasi, maka produk yang memiliki kaitan dengan kegiatan impor akan mengalami kenaikan harga. Kejadian ini menyebabkan biaya produksi meningkat dan laba perusahaan menjadi turun sehingga return yang ditawarkan akan menurun pula. Penurunan return akan mengakibatkan permintaan terhadap saham tersebut berkurang sehingga indeks harga saham menjadi turun ${ }^{3}$.

Minyak mentah atau yang juga dikenal sebagai crude oil merupakan kebutuhan utama dunia saat ini. Kenaikan harga minyak mentah akan memicu naiknya harga barang kebutuhan lainnya. Hal ini karena berbagai kegiatan dalam industri menggunakan minyak sebagai bahan bakarnya. Jika harga barang naik, ada kemungkinan penjualan akan menurun sehingga akan menurunkan laba perusahaan. Turunnya laba perusahaan akan menyebabkan harga saham perusahaan tersebut turun sehingga indeks harga saham juga turun 4 .

Emas banyak dipilih sebagai salah satu bentuk investasi karena nilainya cenderung stabil dan naik. Kenaikan harga emas akan mendorong investor untuk memilih berinvestasi emas daripada berinvestasi di pasar modal. Sebab dengan resiko yang relatif lebih rendah, emas dapat memberikan hasil imbal balik yang baik dengan kenaikan harganya. Ketika banyak investor yang mengalihkan investasinya kedalam bentuk emas batangan, hal ini akan mengakibatkan turunnya indeks harga saham $^{5}$.

Sementara itu, inflasi menjadi salah satu faktor yang mempengaruhi pergerakan indeks harga saham. Inflasi yang semakin tinggi menjadi sinyal negatif bagi para investor yang berinvestasi di pasar modal. Investor akan cenderung melepas sahamnya jika terjadi peningkatan inflasi, terlebih pada saat terjadi inflasi yang tidak terkendali. Hal ini karena peningkatan inflasi yang tinggi menyebabkan kenaikan 
Islamiconomic: Jurnal Ekonomi Islam

Vol.9 No.2 Juli - Desember 2018

$\overline{\text { risiko investasi pada saham. Di samping itu, juga diiringi oleh pesimisme investor }}$ tentang kemampuan dari modal dalam menghasilkan laba di masa kini dan masa mendatang. Kecendrungan para investor untuk melepas sahamnya akan menyebabkan harga saham tersebut menjadi turun. Terjadinya penuruan harga saham ini akan tercermin pada indeks harga saham6.

Atas dasar uraian di atas, maka rumusan masalah pada penelitian ini adalah:

1. Apakah inflasi Indonesia berpengaruh terhadap Jakarta Islamic Index pada jangka pendek dan jangka panjang?

2. Apakah kurs rupiah terhadap dollar berpengaruh terhadap Jakarta Islamic Index pada jangka pendek dan jangka panjang?

3. Apakah harga minyak mentah dunia berpengaruh terhadap Jakarta Islamic Index pada jangka pendek dan jangka panjang?

4. Apakah harga emas dunia berpengaruh terhadap Jakarta Islamic Index pada jangka pendek dan jangka panjang?

5. Apakah inflasi Malaysia berpengaruh terhadap FTSE Bursa Malaysia Hijrah Syariah Index pada jangka pendek dan jangka panjang?

6. Apakah kurs ringgit terhadap dollar berpengaruh terhadap FTSE Bursa Malaysia Hijrah Syariah Index pada jangka pendek dan jangka panjang?

7. Apakah harga minyak mentah dunia berpengaruh terhadap FTSE Bursa Malaysia Hijrah Syariah Index pada jangka pendek dan jangka panjang?

8. Apakah harga emas dunia berpengaruh terhadap FTSE Bursa Malaysia Hijrah Syariah Index pada jangka pendek dan jangka panjang?

\section{PEMBAHASAN}

\section{Inflasi}

Menurut Karim, inflasi adalah kenaikan yang menyeluruh dari jumlah uang yang harus dibayarkan (nilai unit perhitungan moneter) terhadap barang-barang dan jasa ${ }^{7}$ Sedangkan menurut Utoyo, inflasi adalah kenaikan harga barang secara umum dan terus-menerus selama periode tertentu ${ }^{8}$. Al Maqrizi menggolongkan inflasi menjadi dua golongan yaitu natural inflation dan human error inflation. Natural inflation adalah inflasi yang disebabkan oleh sebab-sebab alamiah. Human error inflation adalah inflasi yang diakibatkan oleh kesalahan dari manusia9 
Desy Trishardiyanti A.: Pengaruh Variable...

\section{Kurs}

Menurut Karim, kurs adalah catatan harga pasar dari mata uang asing dalam harga mata uang domestik atau sebaliknya10. Sedangkan menurut Sukirno, kurs adalah harga atau nilai mata uang sesuatu negara dinyatakan dalam nilai mata uang negara lain ${ }^{11}$. Kurs dapat ditentukan oleh pemerintah seperti pada negara-negara yang memakai sistem fixed exchange rates ataupun ditentukan oleh kombinasi antara kekuatan-kekuatan pasar yang saling berinteraksi serta kebijakan pemerintah seperti pada negara-negara yang memakai sistem flexible exchange rate re $^{12}$

\section{Harga Minyak Mentah Dunia}

Minyak mentah menjadi salah satu sumber energi primer bagi seluruh industri di belahan dunia. Salah satu jenis minyak mentah dunia yang menjadi acuan harga dunia adalah jenis West Texas Intermediate ${ }^{13}$. Minyak mentah jenis West Texas Intermediate (WTI) adalah minyak mentah yang berkualitas tinggi. Hal ini dikarenakan minyak mentah tersebut memiliki kadar belerang yang rendah dan sangat cocok untuk dijadikan bahan bakar ${ }^{14}$.

\section{Harga Emas Dunia}

Sejak tahun 1968, standar pasar emas London dijadikan patokan harga emas dunia. Sistem yang digunakan dikenal dengan The London Bullion Market Association (LBMA). The London Bullion Market Association adalah badan utama yang mengontrol dan menentukan standar harga emas di seluruh dunia. Proses penentuan harga dilakukan dua kali dalam satu hari, yaitu pukul 10.30 (gold a.m) dan pukul 15.00 (gold p.m). Harga yang menjadi patokan harga emas dunia adalah harga penutupan atau gold p.m ${ }^{15}$.

\section{Jakarta Islamic Index}

Di dalam pasar modal syariah Indonesia terdapat indeks yang bernama Jakarta Islamic Index (JII) yang diluncurkan berdasarkan prinsip syariah pada tanggal 3 Juli 2000. Tujuan Jakarta Islamic Index adalah sebagai tolak ukur (benchmark) untuk 
Islamiconomic: Jurnal Ekonomi Islam Vol.9 No.2 Juli - Desember 2018

mengukur kinerja investasi pada saham yang berbasis syariah dan meningkatkan kepercayaan para investor untuk mengembangkan investasi dalam ekuiti syariah ${ }^{16}$.

Berdasarkan fatwa No.40/DSN-MUI/X/2003, kriteria kegiatan usaha yang bertentangan dengan prinsip syariah adalah perjudian dan permainan yang tergolong judi atau perdagangan yang dilarang, lembaga keuangan konvensional termasuk perbankan dan asuransi konvensional, produsen, distributor serta pedagang makanan dan minuman yang haram, produsen, distributor dan penyedia barangbarang ataupun jasa yang merusak moral dan bersifat mudarat, melakukan investasi pada emiten yang pada saat transaksi tingkat hutang perusahaan kepada lembaga keuangan konvensional lebih dominan dari modalnya ${ }^{17}$.

\section{FTSE Bursa Malaysia Hijrah Syariah Index}

FTSE Bursa Malaysia Hijrah Syariah Index dirancang untuk digunakan sebagai dasar produk investasi syariah yang memenuhi persyaratan screening dari investor syariah internasional. Efek yang masuk dalam indeks tersebut disaring oleh Shariah Advisory Council (SAC) Malaysia dan konsultan syariah global terkemuka,Yasaar Ltd ${ }^{18}$.

SAC menetapkan bahwa sebuah saham adalah saham syariah antara lain jika tidak terlibat dalam jasa keuangan berdasarkan riba (bunga), perjudian, industri atau penjualan produk non halal atau produk-produk terkait, asuransi konvensional, kegiatan hiburan yang non halal menurut syariah, industri atau penjualan produk berbasis tembakau atau produk-produk terkait, menjadi broker atau melakukan perdagangan saham non syariah serta kegiatan lain yang dianggap non halal menurut syariah $^{19}$. 
Desy Trishardiyanti A.: Pengaruh Variable...

Model Penelitian

Model Penelitian 1

Gambar 3

Model Penelitian 1

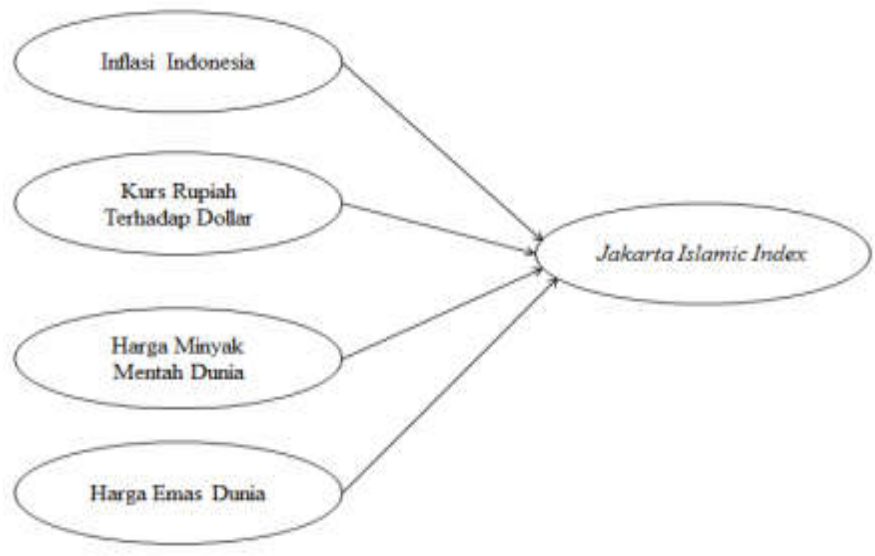

Model Penelitian 2

\section{Gambar 4}

\section{Model Penelitian 2}

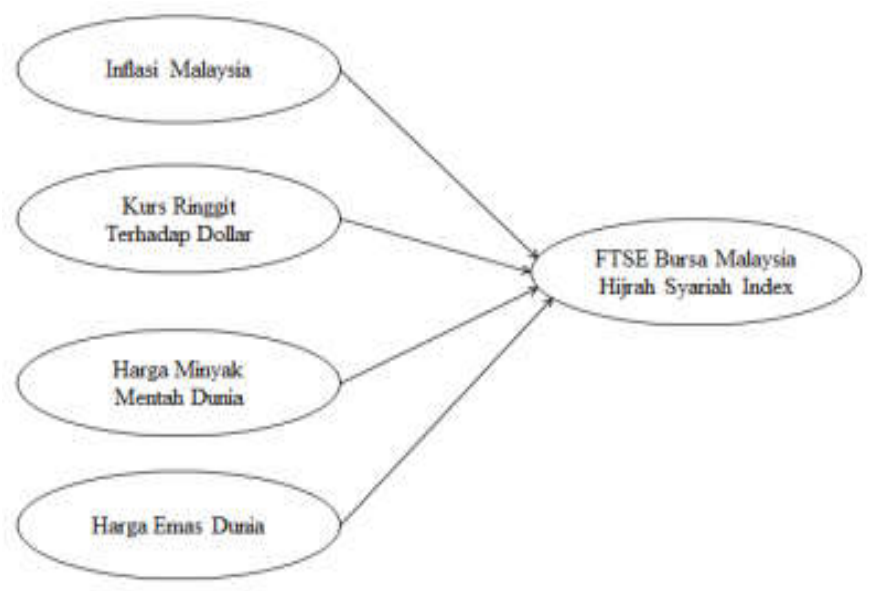

\section{Hipotesis}

$\mathrm{H}_{1 \mathrm{a}}$ : Inflasi Indonesia berpengaruh terhadap Jakarta Islamic Index pada jangka pendek dan jangka panjang.

$\mathrm{H}_{1 \mathrm{~b}}$ : Inflasi Malaysia berpengaruh terhadap FTSE Bursa Malaysia Hijrah Syariah Index pada jangka pendek dan jangka panjang. 
Islamiconomic: Jurnal Ekonomi Islam

Vol.9 No.2 Juli - Desember 2018

$\overline{\mathrm{H}_{2 \mathrm{a}} \text { : Kurs rupiah terhadap dollar berpengaruh terhadap Jakarta Islamic Index pada }}$ jangka pendek dan jangka panjang.

$\mathrm{H}_{2 b}$ : Kurs ringgit terhadap dollar berpengaruh terhadap FTSE Bursa Malaysia Hijrah Syariah Index pada jangka pendek dan jangka panjang.

$\mathrm{H}_{3 a}$ : Harga minyak mentah dunia berpengaruh terhadap Jakarta Islamic Index pada jangka pendek dan jangka panjang.

$\mathrm{H}_{3 \mathrm{~b}}$ : Harga minyak mentah dunia berpengaruh terhadap FTSE Bursa Malaysia Hijrah Syariah Index pada jangka pendek dan jangka panjang.

$\mathrm{H}_{4 \mathrm{a}}$ : Harga emas dunia berpengaruh terhadap Jakarta Islamic Index pada jangka pendek dan jangka panjang.

$\mathrm{H}_{4 b}$ : Harga emas dunia berpengaruh terhadap FTSE Bursa Malaysia Hijrah Syariah Index pada jangka pendek dan jangka panjang.

\section{Jenis Penelitian dan Jenis Data}

Jenis penelitian ini adalah penelitian kuantitatif, penelitian kuantitatif adalah suatu proses menemukan pengetahuan yang menggunakan data berupa angka sebagai alat menemukan keterangan mengenai apa yang ingin kita ketahui ${ }^{20}$. Jenis data yang digunakan dalam penelitian ini adalah data sekunder. Data sekunder adalah data yang didapat dan disimpan oleh orang lain, biasanya merupakan data masa lalu atau historikal21.

\section{Populasi dan Sampel}

Populasi adalah keseluruhan wilayah objek dan subjek penelitian yang ditetapkan untuk dianalisis dan ditarik kesimpulan oleh peneliti22. Populasi dalam penelitian ini adalah data inflasi Indonesia, kurs rupiah terhadap dollar, harga minyak mentah dunia, harga emas dunia, inflasi Malaysia, kurs ringgit terhadap dollar, Jakarta Islamic Index dan FTSE Bursa Malaysia Hijrah Syariah Index periode Maret 2015 sampai dengan Februari 2018.

Sampel adalah objek atau subjek penelitian yang dipilih guna mewakili keseluruhan dari populasi23. Teknik penentuan sampel yang digunakan dalam penelitian ini adalah teknik sampling jenuh (teknik penentuan sampel bila semua anggota populasi digunakan sebagai sampel). Sehingga sampel yang digunakan dalam 158 
Desy Trishardiyanti A.: Pengaruh Variable...

$\overline{\text { penelitian ini adalah data inflasi Indonesia, kurs rupiah terhadap dollar, harga minyak }}$ mentah dunia, harga emas dunia, inflasi Malaysia, kurs ringgit terhadap dollar, Jakarta Islamic Index dan FTSE Bursa Malaysia Hijrah Syariah Index periode Maret 2015 sampai dengan Februari 2018.

\section{Metode analisis}

\section{Uji Augmented Dickey Fuller (ADF)}

Dalam prakteknya uji ADF digunakan untuk mendeteksi apakah data stasioner atau tidak. Adapun formulasi uji ADF adalah sebagai berikut:

$$
\begin{gathered}
\Lambda Y_{i}=\gamma Y_{i-1}+\sum_{i-2}^{p} \beta_{i} \Lambda Y_{i-i+1}+e_{i} \\
\Delta Y_{t}=\alpha_{0}+\gamma Y_{t-1}+\sum_{i=2}^{p} \beta_{i} \Delta Y_{t-i+1}+e_{t} \\
\Delta Y_{t}=a_{0}+\alpha_{1} T+\gamma Y_{t-1}+\sum_{i=2}^{p} \beta_{i} \Delta Y_{t-i+1}+e_{t}
\end{gathered}
$$

dimana, $Y_{t}$ adalah variabel yang diamati, $\Delta Y_{t}=Y_{t}-Y_{t-1}$ dan $T$ adalah tren waktu.

Persamaan (1) merupakan uji tanpa konstanta dan tren waktu. Persamaan (2) merupakan uji dengan konstanta tanpa tren waktu. Sedangkan persamaan (3) merupakan uji dengan konstanta dan tren waktu. Prosedur untuk menentukan apakah data stasioner atau tidak adalah dengan cara membandingkan nilai statistik ADF dengan nilai kritisnya. Jika nilai absolut statistik ADF lebih besar dari nilai kritisnya, maka data stasioner ${ }^{24}$.

\section{Uji Johansen}

Uji kointegrasi dapat dinyatakan sebagai uji terhadap hubungan keseimbangan atau hubungan jangka panjang antara variabel-variabel ekonomi seperti yang dikehendaki dalam teori ekonometrika ${ }^{25}$. Alternatif uji kointegrasi yang sekarang banyak digunakan adalah uji kointegrasi yang dikembangkan oleh Johansen. Johansen menyediakan uji statistik LR alternatif yang dikenal sebagai maximum eigenvalue statistic. Maximum eigenvalue statistic dapat dihitung dari trace statistic sebagai berikut ${ }^{26}$ :

$$
Q_{\max }=-T\left(1-\lambda_{i+1}\right)=Q_{t}-Q_{t+1}
$$




\section{Error Correction Model Engle Granger}

Model umum Error Correction Model Engle Granger adalah sebagai berikut ${ }^{27}$ :

$$
\Delta Y_{t}=\alpha_{0}+\alpha_{1} \Delta X_{t}+\alpha_{2} E C_{t}+e_{*}
$$

dimana $E C_{t}=\left(Y_{t-1}-\beta_{0}-\beta_{1} X_{t-1}\right)$.

$\alpha_{0}$ adalah koefisien konstanta jangka pendek dan $\alpha_{1}$ adalah koefisien jangka pendek sedangkan $\beta_{0}$ adalah koefisien konstanta jangka panjang dan $\beta_{1}$ adalah koefisien jangka panjang. Koefisien koreksi ketidakseimbangan $\alpha_{2}$ dalam bentuk nilai absolut menjelaskan seberapa cepat waktu diperlukan untuk mendapatkan nilai keseimbangan.

\section{Analisis Data dan Hasil Penelitian}

Uji Augmented Dickey Fuller

\section{Tabel 1}

Augmented Dickey Fuller Test pada Level

\begin{tabular}{|c|c|c|c|}
\hline Variabel & Nilai ADF & Prob. & Keterangan \\
\hline Jakarta Islamic Index & $-1,054299$ & 0,7225 & Tidak stasioner \\
\hline Inflasi Indonesia & $-1,323181$ & 0,6078 & Tidak stasioner \\
\hline Kurs rupiah terhadap dollar & $-2,526562$ & 0,1180 & Tidak stasioner \\
\hline Harga minyak mentah dunia & $-1,125579$ & 0,6946 & Tidak stasioner \\
\hline Harga emas dunia & $-1,356637$ & 0,5920 & Tidak stasioner \\
\hline Inflasi Malaysia & $-2,489946$ & 0,1267 & Tidak stasioner \\
\hline Kurs ringgit terhadap dollar & $-2,763895$ & 0,0742 & Tidak stasioner \\
\hline FTSE Bursa Malaysia Hijrah & $-2,762902$ & 0,0740 & Tidak stasioner \\
Syariah Index & & & \\
\hline
\end{tabular}

Sumber: Data penelitian yang diolah.

Augmented Dickey Fuller test pada tabel 1 menunjukan bahwa variabel Jakarta Islamic Index, inflasi Indonesia, kurs rupiah terhadap dollar, harga minyak mentah dunia, harga emas dunia, inflasi Malaysia, kurs ringgit terhadap dollar dan FTSE Bursa Malaysia Hijrah Syariah Index tidak stasioner pada level (karena nilai probabilitas masing-masing variabel lebih besar dari $\alpha=5 \%$ ), sehingga variabel- 
Desy Trishardiyanti A.: Pengaruh Variable...

variabel tersebut perlu diuji stasioneritasnya pada diferensi pertama. Berikut ini adalah hasil uji Augmented Dickey Fuller pada diferensi pertama (first difference) dengan $\alpha=5 \%$ :

Tabel 2

Augmented Dickey Fuller Test pada Diferensi Pertama

\begin{tabular}{|c|c|c|c|}
\hline Variabel & Nilai ADF & Prob. & Keterangan \\
\hline Jakarta Islamic Index & $-6,085534$ & 0,0000 & Stasioner \\
\hline Inflasi Indonesia & $-4,623869$ & 0,0007 & Stasioner \\
\hline Kurs rupiah terhadap dollar & $-5,601695$ & 0,0001 & Stasioner \\
\hline Harga minyak mentah dunia & $-4,608748$ & 0,0008 & Stasioner \\
\hline Harga emas dunia & $-4,916226$ & 0,0003 & Stasioner \\
\hline Inflasi Malaysia & $-3,746139$ & 0,0076 & Stasioner \\
\hline Kurs ringgit terhadap dollar & $-3,781599$ & 0,0070 & Stasioner \\
\hline FTSE Bursa Malaysia Hijrah & $-5,658196$ & 0,0000 & Stasioner \\
Syariah Index & & & \\
\hline
\end{tabular}

Sumber: Data penelitian yang diolah.

Dari tabel 2 di atas, dapat dilihat bahwa Jakarta Islamic Index, inflasi Indonesia, kurs rupiah terhadap dollar, harga minyak mentah dunia, harga emas dunia, inflasi Malaysia, kurs ringgit terhadap dollar dan FTSE Bursa Malaysia Hijrah Syariah Index stasioner pada diferensi pertama (karena nilai probabilitas masing-masing variabel lebih kecil dari $\alpha=5 \%)$.

\section{Uji Kointegrasi Model Penelitian 1}

Tabel 3

Uji Kointegrasi Model Penelitian 1

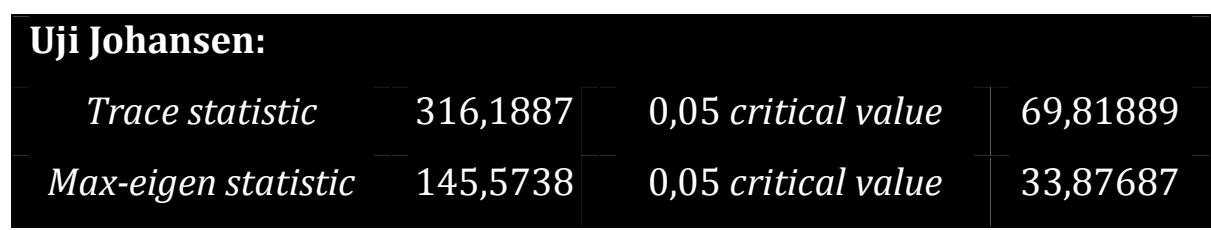

Sumber: Data penelitian yang diolah. 
Pada tabel 3 dapat dilihat bahwa nilai trace statistic $(316,1887)$ lebih besar dari 0,05 critical value $(69,81889)$ dan nilai max-eigen statistic $(145,5738)$ lebih besar dari 0,05 critical value $(33,87687)$, hal tersebut menunjukan bahwa data inflasi Indonesia, kurs rupiah terhadap dollar, harga minyak mentah dunia, harga emas dunia dan Jakarta Islamic Index saling berkointegrasi.

\section{Error Correction Model (ECM) Model Penelitian 1}

\section{Estimasi ECM Jangka Panjang Model Penelitian 1}

Tabel 4

Estimasi ECM Jangka Panjang Model Penelitian 1

\begin{tabular}{|c|c|c|c|c|}
\hline Variable & Coefficient & Std. Error & t-Statistic & Prob. \\
\hline C & 957,5227 & 363,1464 & 2,636740 & 0,0130 \\
\hline INF_IND & $-10,98808$ & 4,501865 & $-2,440784$ & 0,0206 \\
\hline KURS_RP & $-0,055124$ & 0,020730 & $-2,659087$ & 0,0123 \\
\hline HMMD & 2,565892 & 0,743527 & 3,450972 & 0,0016 \\
\hline HED & 0,322878 & 0,105426 & 3,062614 & 0,0045 \\
\hline R-squared & 0,794538 & F-statistic & 29,96988 \\
\hline Adjusted R-squared & 0,768027 & Prob(F-statistic) & 0,000000 \\
\hline
\end{tabular}

Sumber: Data penelitian yang diolah.

Dengan mengacu pada tabel 4 maka model ECM jangka panjang adalah sebagai berikut :

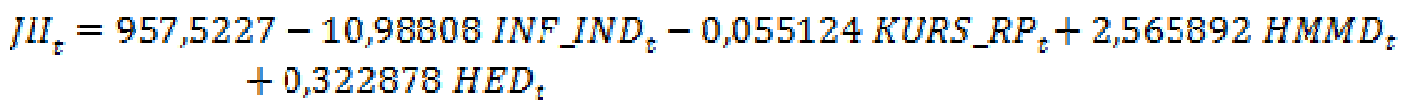

dimana JII adalah Jakarta Islamic Index, INF_IND adalah inflasi Indonesia, KURS_RP adalah kurs rupiah terhadap dollar, HMMD adalah harga minyak mentah dunia dan HED adalah harga emas dunia.

Berdasarkan tabel 4 hasil dari uji t adalah inflasi Indonesia berpengaruh terhadap Jakarta Islamic Index dalam jangka panjang, karena nilai probabilitasnya $(0,0206)$ lebih kecil dari $\alpha=5 \%$. Kurs rupiah terhadap dollar berpengaruh terhadap Jakarta Islamic Index dalam jangka panjang, karena nilai probabilitasnya $(0,0123)$ lebih kecil dari $\alpha=5 \%$. Harga minyak mentah dunia berpengaruh terhadap Jakarta 
Desy Trishardiyanti A.: Pengaruh Variable...

$\overline{\text { Islamic Index dalam jangka panjang, karena nilai probabilitasnya }(0,0016) \text { lebih kecil }}$ dari $\alpha=5 \%$. Dan harga emas dunia berpengaruh terhadap Jakarta Islamic Index dalam jangka panjang, karena nilai probabilitasnya $(0,0045)$ lebih kecil dari $\alpha=5 \%$.

Berdasarkan tabel 4 dapat dilihat bahwa nilai probabilitas F-statistic $(0,000000)$ lebih kecil dari $\alpha=5 \%$, hal tersebut menunjukan bahwa dalam jangka panjang, inflasi Indonesia, kurs rupiah terhadap dollar, harga minyak mentah dunia dan harga emas dunia berpengaruh secara simultan terhadap Jakarta Islamic Index.

Nilai adjusted $\mathrm{R}^{2}$ pada tabel 4 adalah sebesar 0,768027, hal tersebut menunjukan bahwa dalam jangka panjang, kemampuan variasi variabel inflasi Indonesia, kurs rupiah terhadap dollar, harga minyak mentah dunia dan harga emas dunia mampu menjelaskan variasi variabel Jakarta Islamic Index sebesar 76,8027\% dan 23,1973\% variasi variabel Jakarta Islamic Index dijelaskan oleh variasi variabel lain di luar penelitian.

\section{Estimasi ECM Jangka Pendek Model Penelitian 1}

Tabel 5

Estimasi ECM Jangka Pendek Model Penelitian 1

\begin{tabular}{|c|c|c|c|c|}
\hline Variable & Coefficient & Std. Error & t-Statistic & Prob. \\
\hline C & 0,776172 & 3,726321 & 0,208294 & 0,8365 \\
\hline D(INF_IND) & $-2,304573$ & 7,914476 & $-0,291184$ & 0,7730 \\
\hline D(KURS_RP) & $-0,052199$ & 0,018426 & $-2,832875$ & 0,0083 \\
\hline D(HMMD) & 0,230432 & 0,877016 & 0,262745 & 0,7946 \\
\hline D(HED) & 0,187599 & 0,108298 & 1,732240 & 0,0939 \\
\hline EC & $-0,501514$ & 0,142768 & $-3,512780$ & 0,0015 \\
\hline R-squared & 0,487708 & F-statistic & 5,521666 \\
\hline Adjusted R-squared & 0,399382 & Prob(F-statistic) & 0,001086 \\
\hline
\end{tabular}

Sumber: Data penelitian yang diolah.

Dengan mengacu pada tabel 5 maka model jangka pendek adalah sebagai berikut :

$\Delta / H_{t}=0,776172-2,304573 \Delta N F_{-} I N D_{t}-0,052199 \Delta K U R S_{-} R P_{t}$ $+0,230432 \Delta H M M D_{t}+0,187599 \Delta H E D_{t}-0,501514 E C_{t}$ 
Islamiconomic: Jurnal Ekonomi Islam

Vol.9 No.2 Juli - Desember 2018

dimana $\Delta$ JII adalah first difference dari data Jakarta Islamic Index, $\Delta$ INF_IND adalah first difference dari data inflasi Indonesia, $\Delta$ KURS_RP adalah first difference dari data kurs rupiah terhadap dollar, $\triangle \mathrm{HMMD}$ adalah first difference dari data harga minyak mentah dunia dan $\triangle$ HED adalah first difference dari data harga emas dunia.

Nilai probabilitas EC sebesar 0,0015 lebih kecil dari $\alpha=5 \%$, hal tersebut menunjukan bahwa model ECM yang digunakan dalam penelitian ini sudah valid.

Berdasarkan tabel 5, hasil dari uji t adalah inflasi Indonesia tidak berpengaruh terhadap Jakarta Islamic Index dalam jangka pendek, karena nilai probabilitasnya $(0,7730)$ lebih besar dari $\alpha=5 \%$. Kurs rupiah terhadap dollar berpengaruh terhadap Jakarta Islamic Index dalam jangka pendek, karena nilai probabilitasnya $(0,0083)$ lebih kecil dari $\alpha=5 \%$. Harga minyak mentah dunia tidak berpengaruh terhadap Jakarta Islamic Index dalam jangka pendek, karena nilai probabilitasnya $(0,7946)$ lebih besar dari $\alpha=5 \%$. Dan harga emas dunia tidak berpengaruh terhadap Jakarta Islamic Index dalam jangka pendek, karena nilai probabilitasnya $(0,0939)$ lebih besar dari $\alpha=5 \%$.

Berdasarkan tabel 5, dapat dilihat bahwa nilai probabilitas F-statistic $(0,001086)$ lebih kecil dari $\alpha=5 \%$, hal tersebut menunjukan bahwa dalam jangka pendek, inflasi Indonesia, kurs rupiah terhadap dollar, harga minyak mentah dunia dan harga emas dunia berpengaruh secara simultan terhadap Jakarta Islamic Index.

Nilai adjusted $\mathrm{R}^{2}$ pada tabel 5 adalah sebesar 0,399382, hal tersebut menunjukan bahwa dalam jangka pendek, kemampuan variasi variabel inflasi Indonesia, kurs rupiah terhadap dollar, harga minyak mentah dunia dan harga emas dunia mampu menjelaskan variasi variabel Jakarta Islamic Index sebesar 39,9382\% dan 60,0618\% variasi variabel Jakarta Islamic Index dijelaskan oleh variasi variabel lain di luar penelitian.

\section{Uji Asumsi Klasik Model Penelitian 1}

\section{Tabel 6}

Uji Asumsi Klasik Model Penelitian 1

\begin{tabular}{|c|c|c|c|c|c|}
\hline & zalitas & Heteroskedastisitas & Aut & relasi & Linieritas \\
\hline Prob. & 0,829793 & Prob. & Prob & 0,2645 & Prob. $\quad 0,2574$ \\
\hline
\end{tabular}


Desy Trishardiyanti A.: Pengaruh Variable...
Jarque-
$\mathrm{F}(5,29)$
$F(2,27)$
$\mathrm{F}(1,28)$

Bera

Sumber: Data penelitian yang diolah.

Uji normalitas yang digunakan dalam penelitian ini adalah uji Jarque-Bera. Nilai probabilitas pada uji Jarque-Bera adalah sebesar 0,829793 (lebih besar dari $\alpha=5 \%$ ), hal tersebut menunjukan bahwa residual berdistribusi normal (asumsi normalitas terpenuhi).

Uji heteroskedastisitas yang digunakan dalam penelitian ini adalah uji Glejser. Nilai probabilitas $F(5,29)$ pada uji Glejser adalah sebesar 0,4967 (lebih besar dari $\alpha=$ 5\%), hal tersebut menunjukan bahwa tidak terjadi heteroskedastisitas.

Uji autokorelasi yang digunakan dalam penelitian ini adalah Breusch-Godfrey Serial Correlation LM test. Nilai probabilitas $\mathrm{F}(2,27)$ pada Breusch-Godfrey Serial Correlation LM test adalah sebesar 0,2645 (lebih besar dari $\alpha=5 \%$ ), hal tersebut menunjukan bahwa tidak terjadi autokorelasi.

Uji linieritas yang digunakan dalam penelitian ini adalah Ramsey Reset test. Nilai probabilitas $\mathrm{F}(1,28)$ pada Ramsey Reset test adalah sebesar 0,2574 (lebih besar dari $\alpha$ $=5 \%$ ), hal tersebut menunjukan bahwa asumsi linieritas terpenuhi.

\section{Uji Kointegrasi Model Penelitian 2}

\section{Tabel 7}

Uji Kointegrasi Model Penelitian 2

\begin{tabular}{|l|l|l||l|}
\hline Uji Johansen: & \multicolumn{3}{|c|}{} \\
Trace statistic & 372,7502 & 0,05 critical value & 69,81889 \\
Max-eigen statistic & 162,0411 & 0,05 critical value & 33,87687 \\
\hline
\end{tabular}

Sumber: Data penelitian yang diolah.

Pada tabel 7 dapat dilihat bahwa nilai trace statistic $(372,7502)$ lebih besar dari 0,05 critical value $(69,81889)$ dan nilai max-eigen statistic $(162,0411)$ lebih besar dari 0,05 critical value $(33,87687)$, hal tersebut menunjukan bahwa data inflasi Malaysia, kurs ringgit terhadap dollar, harga minyak mentah dunia, harga emas dunia dan FTSE Bursa Malaysia Hijrah Syariah Index saling berkointegrasi. 


\section{Error Correction Model (ECM) Model Penelitian 2}

\section{Estimasi ECM Jangka Panjang Model Penelitian 2}

Tabel 8

Estimasi ECM Jangka Panjang Model Penelitian 2

\begin{tabular}{|c|c|c|c|c|}
\hline Variable & Coefficient & Std. Error & $\boldsymbol{t}$-Statistic & Prob. \\
\hline C & 16592,32 & 1945,254 & 8,529641 & 0,0000 \\
\hline INF_MY & 83,59310 & 78,80947 & 1,060699 & 0,2970 \\
\hline KURS_RG & $-884,3682$ & 375,1238 & $-2,357537$ & 0,0249 \\
\hline HMMD & 17,93496 & 10,79907 & 1,660788 & 0,1068 \\
\hline HED & $-0,029110$ & 1,036445 & $-0,028087$ & 0,9778 \\
\hline$R$-squared & 0,296009 & F-statistic & 3,258657 \\
\hline Adjusted R-squared & 0,205171 & \multicolumn{2}{l|}{ Prob(F-statistic) } & 0,024242 \\
\hline
\end{tabular}

Sumber: Data penelitian yang diolah.

Dengan mengacu pada tabel 8 maka model ECM jangka panjang adalah sebagai berikut :

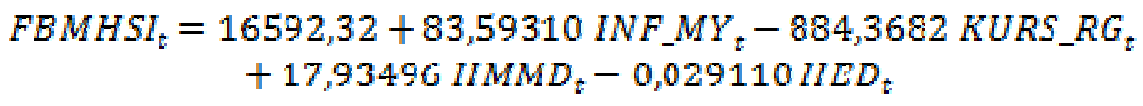

dimana FBMHSI adalah FTSE Bursa Malaysia Hijrah Syariah Index, INF_MY adalah inflasi Malaysia, KURS_RG adalah kurs ringgit terhadap dollar, HMMD adalah harga minyak mentah dunia dan HED adalah harga emas dunia.

Berdasarkan tabel 8, hasil dari uji t adalah inflasi Malaysia tidak berpengaruh terhadap FTSE Bursa Malaysia Hijrah Syariah Index dalam jangka panjang, karena nilai probabilitasnya $(0,2970)$ lebih besar dari $\alpha=5 \%$. Kurs ringgit terhadap dollar berpengaruh terhadap FTSE Bursa Malaysia Hijrah Syariah Index dalam jangka panjang, karena nilai probabilitasnya $(0,0249)$ lebih kecil dari $\alpha=5 \%$. Harga minyak mentah dunia tidak berpengaruh terhadap FTSE Bursa Malaysia Hijrah Syariah Index dalam jangka panjang, karena nilai probabilitasnya $(0,1068)$ lebih besar dari $\alpha=5 \%$. Dan harga emas dunia tidak berpengaruh terhadap FTSE Bursa Malaysia Hijrah Syariah Index dalam jangka panjang, karena nilai probabilitasnya $(0,9778)$ lebih besar dari $\alpha=5 \%$. 
Desy Trishardiyanti A.: Pengaruh Variable...

Berdasarkan tabel 8, dapat dilihat bahwa nilai probabilitas F-statistic $(0,024242)$ lebih kecil dari $\alpha=5 \%$, hal tersebut menunjukan bahwa dalam jangka panjang, inflasi Malaysia, kurs ringgit terhadap dollar, harga minyak mentah dunia dan harga emas dunia berpengaruh secara simultan terhadap FTSE Bursa Malaysia Hijrah Syariah Index.

Nilai adjusted $\mathrm{R}^{2}$ pada tabel 8 adalah sebesar 0,205171, hal tersebut menunjukan bahwa dalam jangka panjang, kemampuan variasi variabel inflasi Malaysia, kurs ringgit terhadap dollar, harga minyak mentah dunia dan harga emas dunia mampu menjelaskan variasi variabel FTSE Bursa Malaysia Hijrah Syariah Index sebesar 20,5171\% dan 79,4829\% variasi variabel FTSE Bursa Malaysia Hijrah Syariah Index dijelaskan oleh variasi variabel lain di luar penelitian.

\section{Estimasi ECM Jangka Pendek Model Penelitian 2}

Tabel 9

Estimasi ECM Jangka Pendek Model Penelitian 2

\begin{tabular}{|c|c|c|c|c|}
\hline Variable & Coefficient & Std. Error & t-Statistic & Prob. \\
\hline C & $-4,090194$ & 49,36675 & $-0,082853$ & 0,9345 \\
\hline D(INF_MY) & $-11,91840$ & 77,22796 & $-0,154328$ & 0,8784 \\
\hline D(KURS_RG) & $-2033,045$ & 633,5957 & $-3,208741$ & 0,0032 \\
\hline D(HMMD) & 9,489212 & 12,36452 & 0,767455 & 0,4490 \\
\hline D(HED) & $-0,806978$ & 1,395205 & $-0,578394$ & 0,5675 \\
\hline EC & $-0,539001$ & 0,144728 & $-3,724248$ & 0,0008 \\
\hline R-squared & 0,389548 & F-statistic & 3,701162 \\
\hline Adjusted R-squared & 0,284298 & Prob(F-statistic) & 0,010324 \\
\hline
\end{tabular}

Sumber: Data penelitian yang diolah.

Dengan mengacu pada tabel 9 maka model jangka pendek adalah sebagai berikut :

$$
\begin{aligned}
\triangle F B M H S I_{t}= & -4,090194-11,91840 \Delta N F M Y_{t}-2033,045 \Delta K U R S_{1} R G_{t} \\
& +9,489212 \triangle H M M D_{t}-0,806978 \Delta H E D_{t}-0,539001 E C_{t}
\end{aligned}
$$

dimana $\triangle$ FBMHSI adalah first difference dari data FTSE Bursa Malaysia Hijrah Syariah Index. $\triangle$ INF_MY adalah first difference dari data inflasi Malaysia. $\Delta$ KURS_RG adalah 
Islamiconomic: Jurnal Ekonomi Islam Vol.9 No.2 Juli - Desember 2018

$\overline{\text { first difference dari data kurs ringgit terhadap dollar. } \triangle \mathrm{HMMD} \text { adalah first difference }}$ dari data harga minyak mentah dunia. Dan $\triangle$ HED adalah first difference dari data harga emas dunia.

Nilai probabilitas $E C$ sebesar 0,0008 lebih kecil dari $\alpha=5 \%$, hal tersebut menunjukan bahwa model ECM yang digunakan dalam penelitian ini sudah valid.

Berdasarkan tabel 9, hasil dari uji t adalah inflasi Malaysia tidak berpengaruh terhadap FTSE Bursa Malaysia Hijrah Syariah Index dalam jangka pendek, karena nilai probabilitasnya $(0,8784)$ lebih besar dari $\alpha=5 \%$. Kurs ringgit terhadap dollar berpengaruh terhadap FTSE Bursa Malaysia Hijrah Syariah Index dalam jangka pendek, karena nilai probabilitasnya $(0,0032)$ lebih kecil dari $\alpha=5 \%$. Harga minyak mentah dunia tidak berpengaruh terhadap FTSE Bursa Malaysia Hijrah Syariah Index dalam jangka pendek, karena nilai probabilitasnya $(0,4490)$ lebih besar dari $\alpha=5 \%$. Dan harga emas dunia tidak berpengaruh terhadap FTSE Bursa Malaysia Hijrah Syariah Index dalam jangka pendek, karena nilai probabilitasnya $(0,5675)$ lebih besar dari $\alpha=5 \%$.

Berdasarkan tabel 9 dapat dilihat bahwa nilai probabilitas F-statistic $(0,010324)$ lebih kecil dari $\alpha=5 \%$, hal tersebut menunjukan bahwa dalam jangka pendek, inflasi Malaysia, kurs ringgit terhadap dollar, harga minyak mentah dunia dan harga emas dunia berpengaruh secara simultan terhadap FTSE Bursa Malaysia Hijrah Syariah Index.

Nilai adjusted $\mathrm{R}^{2}$ pada tabel 9 adalah sebesar 0,284298, hal tersebut menunjukan bahwa dalam jangka pendek, kemampuan variasi variabel inflasi Malaysia, kurs ringgit terhadap dollar, harga minyak mentah dunia dan harga emas dunia mampu menjelaskan variasi variabel FTSE Bursa Malaysia Hijrah Syariah Index sebesar 28,4298\% dan 71,5702\% variasi variabel FTSE Bursa Malaysia Hijrah Syariah Index dijelaskan oleh variasi variabel lain di luar penelitian. 
Desy Trishardiyanti A.: Pengaruh Variable...

Uji Asumsi Klasik Model Penelitian 2

Tabel 10

Uji Asumsi Klasik Model Penelitian 2

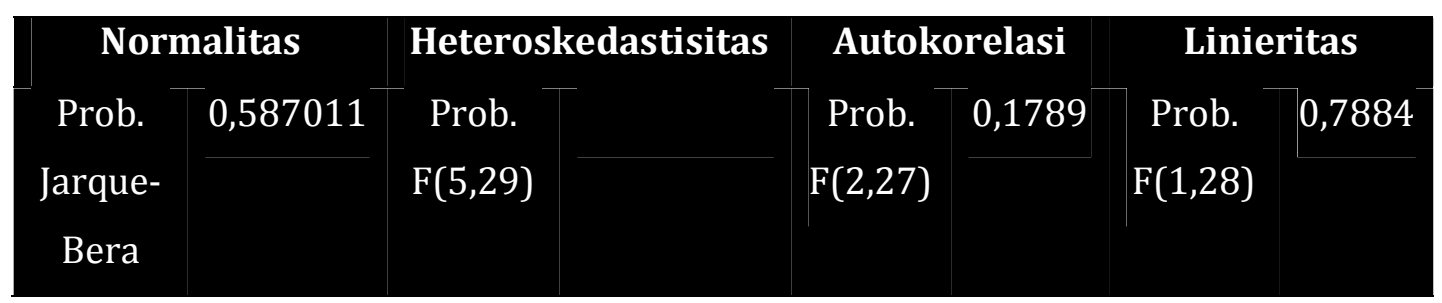

Sumber: Data penelitian yang diolah.

Uji normalitas yang digunakan dalam penelitian ini adalah uji Jarque-Bera. Nilai probabilitas pada uji Jarque-Bera adalah sebesar 0,587011 (lebih besar dari $\alpha=5 \%$ ), hal tersebut menunjukan bahwa residual berdistribusi normal (asumsi normalitas terpenuhi).

Uji heteroskedastisitas yang digunakan dalam penelitian ini adalah uji Glejser. Nilai probabilitas $F(5,29)$ pada uji Glejser adalah sebesar 0,9826 (lebih besar dari $\alpha=$ 5\%), hal tersebut menunjukan bahwa tidak terjadi heteroskedastisitas.

Uji autokorelasi yang digunakan dalam penelitian ini adalah Breusch-Godfrey Serial Correlation LM test. Nilai probabilitas F(2,27) pada Breusch-Godfrey Serial Correlation LM test adalah sebesar 0,1789 (lebih besar dari $\alpha=5 \%$ ), hal tersebut menunjukan bahwa tidak terjadi autokorelasi.

Uji linieritas yang digunakan dalam penelitian ini adalah Ramsey Reset test. Nilai probabilitas F(1,28) pada Ramsey Reset test adalah sebesar 0,7884 (lebih besar dari $\alpha$ $=5 \%$ ), hal tersebut menunjukan bahwa asumsi linieritas terpenuhi.

\section{KESIMPULAN}

1. Dalam jangka pendek, inflasi Indonesia tidak berpengaruh terhadap Jakarta Islamic Index. Sedangkan dalam jangka panjang, inflasi Indonesia berpengaruh terhadap Jakarta Islamic Index.

2. Kurs rupiah terhadap dollar berpengaruh terhadap Jakarta Islamic Index dalam jangka pendek maupun jangka panjang. 
Islamiconomic: Jurnal Ekonomi Islam Vol.9 No.2 Juli - Desember 2018

3. Dalam jangka pendek, harga minyak mentah dunia tidak berpengaruh terhadap Jakarta Islamic Index. Sedangkan dalam jangka panjang, harga minyak mentah dunia berpengaruh terhadap Jakarta Islamic Index.

4. Dalam jangka pendek, harga emas dunia tidak berpengaruh terhadap Jakarta Islamic Index. Sedangkan dalam jangka panjang, harga emas dunia berpengaruh terhadap Jakarta Islamic Index.

5. Inflasi Malaysia tidak berpengaruh terhadap FTSE Bursa Malaysia Hijrah Syariah Index dalam jangka pendek maupun jangka panjang.

6. Kurs ringgit terhadap dollar berpengaruh terhadap FTSE Bursa Malaysia Hijrah Syariah Index dalam jangka pendek maupun jangka panjang.

7. Harga minyak mentah dunia tidak berpengaruh terhadap FTSE Bursa Malaysia Hijrah Syariah Index dalam jangka pendek maupun jangka panjang.

8. Harga emas dunia tidak berpengaruh terhadap FTSE Bursa Malaysia Hijrah Syariah Index dalam jangka pendek maupun jangka panjang.

\section{PUSTAKA ACUAN}

Aprianti, Dita Fitria. Penggunaan Error Correction Model Engle-Granger dan Domowitz El-Badawi Pada Data Analisis Deret Waktu Non Stationer. Jurnal Mahasiswa Statistik, Vol. 2 No. 1, 2014.

Bawono, Anton. Multivariate Analysis dengan SPSS. Salatiga: STAIN Salatiga Press, 2006.

Dewan Syariah Nasional. Fatwa Dewan Syariah Nasional No.40/DSN-MUI/X/2003 Tentang Pasar Modal dan Pedoman Umum Penerapan Prinsip Syariah di Bidang Pasar Modal. Melalui https://drive.google.com/file/d/0BxTlINihFyzSm1BWGZaX19ZQjA/view, 2003.

Gumilang, Reshinta Candra. Pengaruh Variabel Makro Ekonomi, Harga Emas dan Harga Minyak Dunia Terhadap Indeks Harga Saham Gabungan. Jurnal Administrasi Bisnis, Vol. 14 No. 2, 2014.

Hanafiah, Mara Sutan. Pengaruh Harga Minyak Dunia, Nilai Tukar Rupiah Terhadap Dollar dan Tingkat Inflasi Terhadap Harga Saham. Jurnal Administrasi Bisnis, Vol. 28 No. 2, 2015. 
Desy Trishardiyanti A.: Pengaruh Variable...

Husnul, Habib Muhammad. Analisis Pengaruh Inflasi, Kurs (IDR/USD), Produk Domestik Bruto dan Harga Emas Dunia Terhadap Indeks Harga Saham Gabungan. Jurnal Administrasi Bisnis, Vol. 53 No. 1, 2017.

Karim, Adiwarman A. Ekonomi Makro Islami. Jakarta: PT Rajagrafindo Persada, 2015.

Mankiw, N. Gregory. Teori Makroekonomi. Jakarta: Erlangga, 2000.

Oktaviani, Retno Fuji. Index Harga Saham Islamic Internasional Terhadap Jakarta Islamic Index. Jurnal Ekonomika dan Manajemen, Vol. 6 No. 1, 2017.

Pardede, Noel. Pengaruh Harga Minyak Mentah Dunia, Inflasi, Suku Bunga dan Nilai Tukar Terhadap Indeks Harga Saham Sektor Pertambangan di ASEAN. Jurnal Administrasi Bisnis, Vol. 39 No. 1, 2016.

Putri, Ni Made Ari Angga Sari. Pengaruh Harga Emas Dunia dan Nilai Tukar Rupiah Dolar Terhadap Indeks Harga Saham Gabungan. e-Proceeding of Management, Vol. 3 No. 2, 2016.

Shofiyullah, Nur Fu'ad. Komparasi Jakarta Islamic Index dan FTSE Bursa Malaysia Hijrah Shariah Index. Jurnal Bisnis dan Manajemen, Vol. 14 No. 2, 2014.

Sukirno, Sadono. Makroekonomi Teori Pengantar. Jakarta: PT. Rajagrafindo Persada, 2004.

Supriyanto \& Machfudz. Metodologi Riset Manajemen Sumber Daya Manusia. Malang: UIN-Maliki Press, 2010.

Utoyo, Novita Ndari. Pengaruh Tingkat Inflasi, Suku Bunga, Harga Emas Dunia dan Kurs Rupiah Terhadap JII. Jurnal Ilmu dan Riset Akuntansi, Vol. 5 No. 8, 2016.

Wibisono, Dermawan. Riset Bisnis Panduan bagi Praktisi dan Akademisi. Jakarta: Gramedia, 2002.

Widarjono, Agus. Ekonometrika Pengantar dan Aplikasinya. Yogyakarta: UPP STIM YKPN, 2013.

\section{Catatan Akhir:}

1 Retno Fuji Oktaviani, "Index Harga Saham Islamic Internasional Terhadap Jakarta Islamic Index", Jurnal Ekonomika dan Manajemen, Vol. 6 No. 1, (April 2017), 3.

2 Nur Fu'ad Shofiyullah, "Komparasi Jakarta Islamic Index dan FTSE Bursa Malaysia Hijrah Shariah Index”, Jurnal Bisnis dan Manajemen, Vol. 14 No. 2, (2014), 23.

3 Novita Ndari Utoyo, "Pengaruh Tingkat Inflasi, Suku Bunga, Harga Emas Dunia dan Kurs Rupiah Terhadap JII”, Jurnal Ilmu dan Riset Akuntansi, Vol. 5 No. 8, (Agustus 2016), 5. 
Islamiconomic: Jurnal Ekonomi Islam

Vol.9 No.2 Juli - Desember 2018

4 Reshinta Candra Gumilang, "Pengaruh Variabel Makro Ekonomi, Harga Emas dan Harga Minyak Dunia Terhadap Indeks Harga Saham Gabungan”, Jurnal Administrasi Bisnis, Vol. 14 No. 2, (September 2014), 2.

5 Ni Made Ari Angga Sari Putri, "Pengaruh Harga Emas Dunia dan Nilai Tukar Rupiah Dolar Terhadap Indeks Harga Saham Gabungan”, e-Proceeding of Management, Vol. 3 No. 2, (Agustus 2016), 1614.

${ }^{6}$ N. Gregory Mankiw, Teori Makroekonomi (Jakarta: Erlangga, 2000), 434.

7 Adiwarman A. Karim, Ekonomi Makro Islami (Jakarta: PT Rajagrafindo Persada, 2015), 135.

8 Novita Ndari Utoyo, "Pengaruh Tingkat Inflasi, Suku Bunga, Harga Emas Dunia dan Kurs Rupiah Terhadap JII" ..., 3.

${ }^{9}$ Adiwarman A. Karim, Ekonomi Makro Islami ..., 140-142.

10 Adiwarman A. Karim, Ekonomi Makro Islami ..., 157.

11 Sadono Sukirno, Makroekonomi Teori Pengantar (Jakarta: PT. Rajagrafindo Persada, 2004), 397.

12 Adiwarman A. Karim, Ekonomi Makro Islami ..., 157.

13 Noel Pardede, "Pengaruh Harga Minyak Mentah Dunia, Inflasi, Suku Bunga dan Nilai Tukar Terhadap Indeks Harga Saham Sektor Pertambangan di ASEAN", Jurnal Administrasi Bisnis, Vol. 39 No. 1, (Oktober 2016), 132.

14 Mara Sutan Hanafiah, "Pengaruh Harga Minyak Dunia, Nilai Tukar Rupiah Terhadap Dollar dan Tingkat Inflasi Terhadap Harga Saham”, Jurnal Administrasi Bisnis, Vol. 28 No. 2, (November 2015), 3.

15 Habib Muhammad Husnul, “Analisis Pengaruh Inflasi, Kurs (IDR/USD), Produk Domestik Bruto dan Harga Emas Dunia Terhadap Indeks Harga Saham Gabungan”, Jurnal Administrasi Bisnis, Vol. 53 No. 1, (Desember 2017), 69.

16 Retno Fuji Oktaviani, "Index Harga Saham Islamic Internasional Terhadap Jakarta Islamic Index" ..., 3 .

17 Dewan Syariah Nasional, "Fatwa Dewan Syariah Nasional No.40/DSN-MUI/X/2003 Tentang Pasar Modal dan Pedoman Umum Penerapan Prinsip Syariah di Bidang Pasar Modal”, Melalui https://drive.google.com/file/d/0BxTl-INihFyzSm1BWGZaX19ZQjA/view, 2003.

18 Nur Fu'ad Shofiyullah, "Komparasi Jakarta Islamic Index dan FTSE Bursa Malaysia Hijrah Shariah Index"..., 23.

19 Nur Fu'ad Shofiyullah, "Komparasi Jakarta Islamic Index dan FTSE Bursa Malaysia Hijrah Shariah Index"..., 23.

20 Supriyanto \& Machfudz, Metodologi Riset Manajemen Sumber Daya Manusia (Malang: UINMaliki Press, 2010), 201.

21 Dermawan Wibisono, Riset Bisnis Panduan bagi Praktisi dan Akademisi (Jakarta: Gramedia, 2002) 119.

${ }^{22}$ Anton Bawono, Multivariate Analysis dengan SPSS (Salatiga : STAIN Salatiga Press, 2006), 28.

23 Anton Bawono, Multivariate Analysis dengan SPSS ..., 28.

24 Agus Widarjono, Ekonometrika Pengantar dan Aplikasinya (Yogyakarta: UPP STIM YKPN, 2013), 309-310.

25 Dita Fitria Aprianti, "Penggunaan Error Correction Model Engle-Granger dan Domowitz ElBadawi Pada Data Analisis Deret Waktu Non Stationer", Jurnal Mahasiswa Statistik, Vol. 2 No. 1, (2014), 45.

${ }^{26}$ Agus Widarjono, Ekonometrika Pengantar dan Aplikasinya ..., 318-319.

27 Dita Fitria Aprianti, "Penggunaan Error Correction Model Engle-Granger dan Domowitz ElBadawi Pada Data Analisis Deret Waktu Non Stationer" ..., 46. 